\section{Synergistic Activity of Silver Nanoparticles and Vancomycin Against a Spectrum of}

\section{Staphylococcus aureus Biofilm Types}

Running title: Nanoparticles and vancomycin reduce $S$. aureus biofilms

*Hair, Bryan B., *Conley, Matthew E., Wienclaw, Trevor M., Conley, Mark J., and ${ }^{\#}$ Berges, Bradford K.

*These authors contributed equally to this work

Address: Department of Microbiology and Molecular Biology, Brigham Young University, Provo, UT 84602, USA

\footnotetext{
\#Correspondence to Brad Berges at Email: brad.berges@gmail.com
}

Telephone: 1-801-422-8112 


\section{Abstract}

Staphylococcus aureus (SA) is an important human pathogen, causing potentially lethal

21 infections of the blood, skin, and lungs. SA is becoming increasingly difficult to treat due to

22 high levels of antibiotic resistance, and new treatments are needed. SA is able to evade

23 antibiotics and immune surveillance through biofilm development. Biofilms are communities of

24 microorganisms that are able to prevent the entry of antimicrobials and immune cells. Biofilms

25 are also involved in SA transmission because biofilms can form on medical devices. In this

26 study, we tested silver nanoparticles and vancomycin for their anti-biofilm effects on SA. We

27 used 10 different SA isolates, representing a spectrum of biofilm-forming ability, and a crystal

28 violet assay to measure biofilm mass. $2 \mu \mathrm{g} / \mathrm{mL}$ vancomycin treatment resulted in a significant

29 reduction in established SA biofilms in 7/10 isolates, including 4/5 methicillin susceptible SA

30 (MSSA) and 3/5 methicillin-resistant (MRSA) isolates (mean reduction in crystal violet stain of

$31 \quad 13.0 \%$; high of $26.5 \%$ and low of $0 \%$ ). Silver nanoparticle treatment of SA biofilms resulted in a

32 significant reduction in 6/10 isolates, including 4/5 MSSA and 2/5 MRSA (mean reduction of

$338.7 \%$; high of $21.2 \%$ and low of $0 \%$ ). A combinatorial treatment with silver nanoparticles and

34 vancomycin resulted in significant reductions in $9 / 10$ isolates (mean reduction of 20.8\%; high of

$3539.3 \%$ and low of $0 \%$ ). We conclude that both vancomycin and silver nanoparticle treatment of

36 established tissue culture-based SA biofilms result in significant reductions in biofilm mass, with

37 a combinatorial treatment even more effective than either treatment alone. 


\section{Introduction}

40

42

Staphylococcus aureus (SA) is a widespread commensal bacterium that, because of its pathogenicity and ability to persist in hospital settings, has become a global healthcare concern. This gram positive coccus colonizes the anterior nares of roughly $30 \%$ of the population, and several of its characteristics allow it to become virulent and disseminate effectively through the host (1). Epidemiological reports estimate that there are annually 477,927 hospitalizations and 29,164 deaths that were related to SA in the United States alone (2). In addition to antibiotic resistance, the ability to form a community of cells, or biofilm, is a virulence factor that can promote transmission and exacerbate disease.

Bacterial biofilms are ubiquitous and likely the predominant form in which most prokaryotes exist in nature (3). As bacterial cells grow collectively, they are able to create a protective extracellular matrix and initiate other processes that ultimately increase their viability. Potential benefits include amplified resistance to bactericidal agents such as antibiotics, bacteriophage, and host immune defenses (4). Often, multiple bacterial species are incorporated into a single biofilm, and this can facilitate horizontal gene transfer (5). S. aureus has numerous proteins on its outer membrane (Microbial Surface Components Recognizing Adhesive Matrix Molecules) that allow cells to adhere to a wide variety of surfaces (6). Once adhered, a distinct set of genes become activated, resulting in the formation of a biofilm (7). Exopolysaccharides, proteins, extracellular DNA (eDNA), and other polymers have been identified as some of the important constituents of the extracellular matrix that promote intercellular adhesion $(8,9)$. Although there is a spectrum of biofilm types in SA, in general they are often characterized as being either polysaccharide-based or eDNA and protein-based (10). 
63 SA isolates that have arisen from the community and entered hospitals, there are currently only

64 five major clonal lineages of $S$. aureus that account for the majority of nosocomial infections at a

65 global level (11). When one such strain arose in Brazil during the 1990s, it was discovered that it

66 had a much greater ability to produce biofilms and to adhere to polystyrene surfaces (in addition

67 to being multi-drug resistant, a property shared by other strains) $(6,12)$. It could thereby

68 effectively colonize prosthetic devices, catheters, and damaged tissues.

Antibiotics have saved millions of lives, but their common use has resulted in widespread

antibiotic resistance. Within one year of the introduction of methicillin as an antibiotic, resistant

71 strains of SA had already been discovered (methicillin-resistant SA or MRSA) (13). SA is

72 equipped with a mobile genetic element known as the staphylococcal cassette chromosome

73 (SCC) mec. SCCmec can integrate into the bacterial chromosome and promotes the capture and

74 sharing of foreign DNA segments between SA isolates and even other species of bacteria (6)

75 (14). SCCmec often carries a gene that encodes $\beta$-lactam resistance (mecA), in addition to

76 numerous other resistance genes against non- $\beta$-lactam antibiotics (15). In the short time since the

77 first reported MRSA, these genes have proliferated and become increasingly common. Based on

78 isolates gathered from intensive care units, roughly $65 \%$ of the strains currently encountered in

79 hospitals have a copy of mecA and are resistant to methicillin (16).

80 Vancomycin is now one of our final recourses for treating infections caused by multi-

81 drug resistant SA. In 1996, strains of MRSA from Japan were the first recorded isolates that

82 exhibited resistance to vancomycin $(15,17)$. Another independently evolved strain emerged in

832002 that resulted from the transfer of the vanA gene from enterococci, which conferred

84 vancomycin resistance to SA (18). These strains pose an unsettling dilemma to physicians as 
there are now no widely accepted treatment options available for these strains. Furthermore, vancomycin is a large glycopeptide and because of its size is less effective at penetrating exopolysaccharides, like those created by the intercellular adhesion gene cluster in staphylococci (19). Similarly, the bactericidal mechanism only acts upon dividing cells, and because cell growth is decreased in biofilms, its potency and effect are marginalized $(20,21)$. For these reasons, even susceptible SA isolates can be difficult to treat and are requiring greater concentrations of antibiotic to achieve the same effect (22). In comparison to $\beta$-lactam antibiotics, vancomycin is associated with higher rates of treatment failure, persistent bacteremia, clinical relapse, and toxicity to the host (23), making it a less than ideal last resort.

The drawbacks of vancomycin, and antibiotics in general, have spurred investigations for possible alternatives. Silver nanoparticles are receiving attention and may show promise as an antibiotic because of their ability to inhibit and eliminate the growth of a wide array of bacteria, including SA (24). The nanoparticles release $\mathrm{Ag}^{+}$ions into solution, which in turn interact with water to create reactive oxygen species (ROS). ROS are able to penetrate biofilms and cell membranes, and subsequent to their entry, they damage cellular components resulting in cell death (25). Human cells have a greater ability to deal with ROS, so at low concentrations silver nanoparticles may be safe for use in humans (26). The mechanisms utilized by silver nanoparticles to kill bacteria are highly conserved and operate on multiple systems; this suggests that the acquisition of resistance is unlikely (27). It should be noted, however, that such agents require high concentrations to achieve their desired effects, and they are able to eliminate bacterial growth to a limited extent $(24,28,29)$.

Innovative researchers have sought to use silver nanoparticles in conjunction with antibiotics to increase their potency. Though the mechanism behind their interactions has yet to 
108 be fully elucidated, there is a clear synergy when they are used in tandem $(30,31)$. A recent

109 study went one step further to determine if this synergy would also prevail against established

110 biofilms. They successfully demonstrated that biofilms composed of Pseudomonas aeruginosa

111 synergistically reduced by aztreonam and silver nanoparticles (32). No current studies have

112 examined if, and to what level, this synergy is present between vancomycin and silver

113 nanoparticles on SA.

114 The aim of the present study was to examine the susceptibility of SA biofilms to

115 vancomycin and silver nanoparticles. We first characterized each isolate's biofilm type via a

116 crystal violet stain, either untreated or with proteinase or DNase treatments intended to identify

117 components in the biofilm. We chose a spectrum of SA isolates, then silver nanoparticles and

118 vancomycin were tested individually for anti-biofilm activity against a number of MRSA and

119 MSSA strains, including those from hospital isolates and from strains isolated in the community.

120 Next, silver nanoparticles and vancomycin were tested together to determine if they produced

121 synergistic results against SA biofilms.

122 


\section{Results}

124

125

126

127

128

129

130

131

132

133

134

135

136

137

138

\section{Strain characterization for biofilm potential}

A number of different SA isolates were analyzed for biofilm-forming capacities and susceptibility to biofilm disruption in these studies. Various attributes of these isolates are presented in Table 1, including the source of the strain, susceptibility/resistance to methicillin, presence of the icaD gene (involved in polysaccharide biofilm formation), colony morphology on congo red agar (indicates slime/polysaccharide production), baseline biofilm mass (via crystal violet stain), and biofilm susceptibility to proteinase $\mathrm{K}$ and DNase treatment. A commonly used crystal violet biofilm assay was employed in these studies (see Methods).

Overall, 5 MRSA strains and 5 MSSA strains were characterized for biofilm development and composition, including 6 isolates from ATCC or BEI Resources that are publicly available. Most isolates were positive for the icaD gene (7/10), and colony morphology on congo red agar was also assessed (6/10 isolates scored as +++$)$. The baseline biofilm mass in untreated samples treatment) varied amongst the isolates examined, with an OD595nm range of $0.51+/-0.031$ to $3.40+/-0.12$. Overall, a breadth of SA isolates was examined in an effort to represent potential SA strains in the environment.

Treatment of biofilms with proteinase K or DNase can reveal the relative contribution of extracellular proteins or DNA to the structure of a biofilm. We found that some biofilms were similarly affected by either proteinase K or DNase treatment (6/10 total isolates, including 3/5 MRSA and 3/5 MSSA). Some biofilms were more affected by proteinase $\mathrm{K}$ than by DNase (3/10 total isolates, including 2/5 MRSA and 1/5 MSSA), and that one isolate was more affected by DNase than by proteinase K (a MSSA). One MRSA isolate was completely resistant to 
145 DNase treatment (HA1), and one MSSA isolate was completely resistant to proteinase K treatment (SA 25923).

151 (or $\mathrm{ddH}_{2} \mathrm{O}$ as an untreated control; see Fig. 1). We found significant reductions in biofilm

152 staining in $7 / 10$ isolates, with a mean reduction in biofilm mass of $13.0+/-2.7 \%(\mathrm{p}=0.0009)$.

153 MRSA isolates and MSSA isolates were similar in their susceptibility to vancomycin, with 3/5

154 MRSA isolates susceptible (mean reduction of 12.3+/-5.1\%; $\mathrm{p}=0.04$ ) and 4/5 MSSA isolates 155 susceptible (mean reduction of $13.6+/-2.4 \% ; \mathrm{p}=0.006$ ). There was no significant difference in MRSA vs MSSA susceptibility to vancomycin ( $\mathrm{p}=0.38)$.

\section{Evaluation of silver nanoparticles for anti-biofilm activity}

Silver nanoparticles have anti-microbial properties due to the production of reactive oxygen species (33). Eukaryotic cells have a greater ability to neutralize reactive oxygen species as compared to prokaryotes, and so silver nanoparticles may have potential as a treatment for human infections. In order to determine the anti-biofilm effects of silver nanoparticles, biofilms were established for $24 \mathrm{~h}$ and then $2 \mu \mathrm{g} / \mathrm{mL}$ of $10 \mu \mathrm{m}$ silver nanoparticles was added (or citrate

163 buffer as an untreated control; nanoparticles are suspended in this buffer). We found significant 164 reductions in biofilm staining (Fig. 2) when analyzing all $10 \mathrm{SA}$ isolates together as compared to 165 untreated controls (mean reduction of $8.7+/-2.4 \% ; \mathrm{p}=0.03$ ). MRSA isolate biofilms showed a 
167 significant $(\mathrm{p}=0.17)$. 3/5 MRSA isolates were susceptible (mean reduction of 11.3+/-3.4\%;

$168 \mathrm{p}=0.01$ ). Overall, MSSA isolate biofilms were not significantly affected by silver nanoparticle

169 treatment; however 2/5 individual isolates showed significant reductions (mean reduction of

$170 \quad 6.1+/-3.2 \% ; \mathrm{p}=0.32)$.

171 Synergistic effects of silver nanoparticles and vancomycin on biofilms

In order to determine if the combination of silver nanoparticles and vancomycin would

173 have greater effects as compared to either treatment alone, we treated SA biofilms with both

174 agents simultaneously (or citrate buffer as an untreated control; nanoparticles are suspended in

175 this buffer) and then measured biofilm mass (Fig. 3). We found that 9/10 SA strains showed

176 significant biofilm reductions, and with a mean reduction in biofilm mass of $20.8+/-3.8 \%$

$177(\mathrm{p}=0.0003)$. MRSA isolate biofilms showed a greater susceptibility to the combination

178 treatment, with a mean reduction of $25.3+/-3.6 \%(\mathrm{p}=0.0008)$. MSSA strains showed a mean

179 reduction of $16.3+/-6.4 \%(\mathrm{p}=0.04)$. However, there was no significant difference in MRSA vs

180 MSSA susceptibility to the combination treatment $(\mathrm{p}=0.17)$. 1 MSSA isolate (SA6538) was

181 resistant to either treatment alone, and also resistant to the combination treatment. This isolate

182 had the weakest baseline biofilm mass, and was somewhat susceptible to both proteinase $\mathrm{K}$ and

183 DNase. We also noted that the 2 MRSA isolates that were not significantly affected by either

184 treatment alone were susceptible to a combinatorial treatment.

We then analyzed our data by strain type (MRSA, MSSA, or total SA) to determine if

187 treatments mentioned above (Fig. 4). We found that the combinatorial treatment was the most 
189 always found. For MRSA isolates, the combination treatment was more effective at reducing

190 biofilm mass than either vancomycin $(\mathrm{p}=0.05)$ or silver nanoparticles alone $(\mathrm{p}=0.01)$. For MSSA

191 isolates, the combination treatment was more effective at reducing biofilm mass than silver

192 nanoparticles alone ( $\mathrm{p}=0.04)$, and we also found that vancomycin treatment was more effective

193 than silver nanoparticles alone $(\mathrm{p}=0.05)$. When all SA isolates were analyzed together, we found

194 that the combination treatment was more effective than either vancomycin $(\mathrm{p}=0.04)$ or silver

195 nanoparticles alone $(\mathrm{p}=0.001)$. 


\section{Discussion}

In this study, we have characterized 10 different SA isolates for their relative biofilmforming capacity and composition. We tested strains for their resistance to oxacillin (MRSA vs MSSA), and we also detected the presence of the icaD gene (involved in polysaccharide biofilm

201 formation). We also measured the baseline biofilm mass and examined biofilm susceptibility to

202 either proteinase K or DNase. The isolates used were quite varied in these different parameters, 203 indicating that the isolates chosen adequately represent isolates to be encountered in clinical 204 scenarios.

Next, we tested both an antibiotic (vancomycin) and an anti-microbial compound (silver nanoparticles) for anti-biofilm activity against a spectrum of SA isolates representing various antibiotic resistances, biofilm compositions, and relative biofilm strengths. We found that $4 / 5$ MSSA isolate biofilms were significantly reduced following vancomycin treatment, but only $2 / 5$ were reduced by silver nanoparticle treatment. 3/5 MRSA isolate biofilms were reduced by each treatment. 9/10 SA isolate biofilms were significantly reduced by a combinatorial treatment of vancomycin and silver nanoparticles.

Biofilms serve as defense mechanisms against immune cells and soluble immune factors,

213 and also against drug treatment. SA biofilms tend to form canyon-like structures (10) that allow

214 for oxygen and nutrient penetration, but are thought to prevent cells or large molecules from

215 penetrating the biofilm. Vancomycin is a relatively large antibiotic (MW 1449), and as such is

216 not expected to be very effective in treating SA biofilms due to poor penetration. Although 7/10

217 isolates tested showed significant reductions with $2 \mu \mathrm{g} / \mathrm{mL}$ vancomycin treatment, overall the 218 reductions were relatively minor with a mean reduction in biofilm mass of $13.0+/-2.7 \%$. This 
finding may be reflective of the large size of vancomycin. We found no significant difference in vancomycin susceptibility between MRSA and MSSA strains. Susceptible isolates were icaD+ or icaD-, had with high or low scores in the congo red agar test, showed either strong or weak biofilm staining characteristics in a crystal violet assay, and their biofilms were susceptible to proteinase K or DNase treatments. These results suggest that vancomycin has broad spectrum activity against SA biofilms, but overall the reduction in biofilm mass is relatively minor in a tissue culture test.

Silver nanoparticles are known to have toxic properties when exposed to cells. The proposed mechanism is via the formation of reactive oxygen species as silver ions are released. Silver nanoparticles have been explored for activity against a number of pathogenic bacteria, including SA $(34,35)$. They have also been shown to be able to prevent SA biofilm formation $(36,37)$. However, their activity against established SA biofilms has not been extensively explored. One report showed that they are effective against Pseudomonas aeruginosa biofilms (38). In that study, they examined biofilm structures following silver nanoparticle treatment and found that $10 \mathrm{~nm}$ nanoparticles penetrate into the biofilm matrix more effectively than other sizes, resulting in greater activity of aztreonam against lipid bilayers in the target cells.

We found that silver nanoparticle treatment of established SA biofilms has activity against both MRSA and MSSA isolates, but that more isolates are unaffected by this treatment (5/10 affected) as compared to vancomycin (7/10 affected). No clear patterns emerged amongst the isolates that were resistant to silver nanoparticle treatment; these isolates could have a strong or a weak base biofilm mass, they could be resistant to proteinase $\mathrm{K}$ treatment or DNase treatment, and some strains were equally susceptible to proteinase K or DNase treatments. 
Our final set of tests was a combinatorial treatment of silver nanoparticles and

242

243

244

245

vancomycin. We found that 9/10 SA isolates showed significant reductions in biofilm staining following this dual treatment, suggesting that the two treatments work in concert to eliminate biofilm mass. The dual treatment was more effective than either treatment alone for the group of MRSA isolates, and also for all SA isolates, but not for the group of MSSA isolates alone.

Interestingly, we noted that the same two MRSA isolates (M1 and M7) that showed biofilm resistance to vancomycin treatment were also resistant to silver nanoparticle treatment. These two isolates had similar effects following treatment with proteinase $\mathrm{K}$ or with DNase, and also had similar baseline biofilm staining results (see Table 1). Strain M7 lacked the icaD gene, while strain M1 contained this gene, and both strains gave similar colony morphologies on congo red agar (+++). 1 MSSA isolate (SA6538) was resistant to both singular treatments, and was also the only strain resistant to the combinatorial treatment. This isolate had a weak baseline biofilm mass, was ++ on the congo red agar test, lacked the icaD gene, and was somewhat susceptible to both proteinase K and DNase. Interestingly, although this strain had the weakest biofilm mass of any isolate tested, it did have similar susceptibility to proteinase $\mathrm{K}$ and DNase treatments when compared to strains M1 and M7.

SA biofilms have clinical relevance in terms of both transmission, and in vivo pathogenesis after host invasion. These findings could be useful both to prevent transmission via treatment of catheter materials, and also for treatment of established biofilms in vivo. Future directions could include analysis of other antibiotics, such as those with a smaller molecular weight. Other types of metal nanoparticles, or nanoparticles of varying sizes, could also be explored for anti-SA biofilm activity. 
Materials and Methods

264

\section{Isolation and sources of SA}

Nine SA strains were used in this study. Strains M1, M6 and M7 were isolated from a VA).

271

\section{Characterization of biofilms by congo red agar colony morphology}

275 resulting growth was then categorized according to color as,,-+++ , or +++ ; with - being bright red colonies with no black around the colonies; + being mostly red with black colonies only in high-density areas, ++ being almost entirely black with some red colonies, and +++ being all

278 colonies being black (40).

\section{icaD genotyping}

282 Primers used were F: (5' - GAACCGCTTGCCATGTGTTG - 3') and R: (5' -

283 GCTTGACCATGTTGCGTAACC - 3') giving a product of 483 bp as described by (42), and

285 described by each source with the exception that we performed 40 cycles of the amplification

286 step in each reaction. We used a standardized reaction mixture of $25 \mu 1$, consisting of $15.8 \mu 1$ 
287

288

289

290

291

292

293

294

295

296

297

298

299

300

301

302

303

304

305

306

307

308

309

$\mathrm{ddH}_{2} \mathrm{O}, 2.5 \mu \mathrm{l}$ of PCR buffer $\left(15 \mathrm{mM} \mathrm{MgCl}_{2}\right), 2.5 \mu 1 \mathrm{dNTPs}(2.5 \mathrm{mM}), 1 \mu \mathrm{l}$ of each primer $(5 \mu \mathrm{M}$

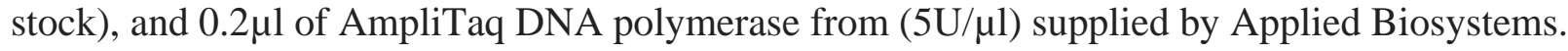
PCR products were visualized under UV light on a $1 \%$ agarose gel stained with ethidium bromide.

\section{Crystal Violet biofilm assay}

Biofilm mass was measured using an adaptation of a previously described assay using 96-well plates $(43,44)$. Strains to be tested were grown overnight at $37^{\circ} \mathrm{C}$ in tryptic soy broth (TSB) (Sigma-Aldrich, St. Louis, MO). Cultures were then diluted 1:200 in 66\% TSB with 0.5\% glucose added. $200 \mu \mathrm{L}$ of culture dilution were added to the wells of a 96-well, flat-bottomed, tissue-culture plate (Falcon \#353916, Corning Incorporated, Corning, NY) in quadruplicate, covered, and incubated for 24 hours at $37^{\circ} \mathrm{C}$. The liquid and non-adhered cells were then removed from the wells by gently overturning the plate onto paper towels. Each well was then gently washed with 1x phosphate-buffered saline (PBS) and allowed to dry. Once dry, $205 \mu \mathrm{L}$ of $100 \%$ ethanol was added to each well to fix the biofilms, incubated for 15 minutes at room temperature, and then emptied onto a paper towel. Once the ethanol had dried $205 \mu \mathrm{L}$ of $0.1 \%$ crystal violet dye was added to each well and incubated for 15 minutes at room temperature. The dye was then emptied as before, by overturning the plate onto paper towels, and three washes with $210 \mu \mathrm{L}$ of $\mathrm{ddH}_{2} \mathrm{O}$ were performed, dumping the water between each wash. Once dry, stain was eluted from the biofilms with $205 \mu \mathrm{L}$ of a mixture of $1 / 3$ volume of EtOH with $40 \mathrm{mM} \mathrm{HCl}$ and 2/3 volume of acetone added to each well. The wells were sealed and incubated with this solution for 15 minutes at $37^{\circ} \mathrm{C}$ with $100 \mathrm{rpm}$ shaking. $80 \mu \mathrm{L}$ of eluted stain was removed from each well and transferred to a new plate for reading and the absorbance at 595nm was measured 
310 for each well. All crystal violet biofilm measurements in these studies were conducted in

311 quadruplicate, and then repeated again in quadruplicate, for a total of 8 independent

312 measurements.

\section{Treatments to disrupt biofilms}

The biofilms used for this test were grown as previously described in the crystal violet

317 emptied onto paper towels. This was done in one quick, yet gentle motion to preserve the biofilm

318 structure. When the wells were fully emptied each well designated for one of three treatments

319 was inoculated with $210 \mu \mathrm{L}$ of either vancomycin at a concentration of $2 \mu \mathrm{g} / \mathrm{mL}$ or $10 \mathrm{~nm}$ silver

$3212 \mu \mathrm{g} / \mathrm{mL}$ vancomycin and $10 \mathrm{~nm}$ silver nanoparticles at $2 \mu \mathrm{g} / \mathrm{mL}$. The controls were also

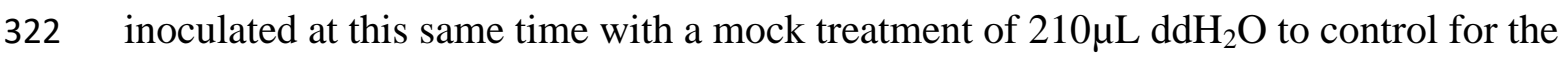

323 vancomycin treatment and $210 \mu \mathrm{L}$ of sodium citrate at a concentration of $2 \mathrm{mM}$ to control for the

324 silver nanoparticle treatment and also for the combination treatment. The samples were

325 incubated at $37^{\circ} \mathrm{C}$ for 24 hours. At the end of the $24 \mathrm{~h}$ period the wells were again emptied by

326 dumping the contents onto paper towels and were left upside down for approximately 24-48h, or

327 until completely dried out. Once dry, the biofilms were fixed, stained, washed and eluted as

328 mentioned in the Crystal Violet biofilm assay section.

\section{Statistical analysis}




\section{Acknowledgements}

333 This research was supported by a BYU Turkey Vaccine Award to BKB, and a BYU ORCA

334 award to BBH. The funders had no role in study design, data collection and interpretation, or the 335 decision to submit the work for publication.

336 We are grateful to Richard Robison (Brigham Young University) and Russell Osguthorpe

337 (Primary Children's Hospital, Salt Lake City, UT) for sharing human MRSA isolates. Some SA

338 isolates were obtained from the American Type Culture Collection and from BEI Resources. 


\section{Figure Legends}

Figure 1: Vancomycin treatment reduces biofilm mass of certain SA strains. Established SA

biofilms (24hr of growth) were treated with $2 \mu \mathrm{g} / \mathrm{mL}$ vancomycin for $24 \mathrm{~h}$ and then fixed and

Figure 2: Silver nanoparticle treatment reduces biofilm mass of certain SA strains.

350

Established SA biofilms (24hr of growth) were treated with $2 \mu \mathrm{g} / \mathrm{mL} \mathrm{Ag}$ nanoparticles for $24 \mathrm{~h}$ and then fixed and stained with crystal violet and absorbance as read at $595 \mathrm{~nm}$. The error bars reflect the standard error and $\mathrm{p}$-values below 0.05 ( $*$ for $\mathrm{p} \leq 0.05$; ** for $\mathrm{p} \leq 0.01)$ are considered significant. Dark gray are MRSA strains, light gray are MSSA strains. The controls were inoculated at the same time with a mock treatment of $210 \mu \mathrm{L}$ citrate buffer.

\section{Figure 3: Silver nanoparticle and vancomycin combined treatment reduces biofilm of most}

SA strains. Established SA biofilms (24hr of growth) were treated with $2 \mu \mathrm{g} / \mathrm{mL} \mathrm{Ag}$

nanoparticles and $2 \mu \mathrm{g} / \mathrm{mL}$ vancomycin for $24 \mathrm{~h}$ and then fixed and stained with crystal violet and absorbance read at 595nm. The error bars reflect the standard error and p-values below 0.05

$(*$ for $\mathrm{p} \leq 0.05 ; * *$ for $\mathrm{p} \leq 0.01)$ are considered significant. Dark gray are MRSA strains, light gray 
361 are MSSA strains. The controls were inoculated at the same time with a mock treatment of

$362210 \mu \mathrm{L}$ citrate buffer.

363

364 Fig 4: Susceptibility of SA strains to various treatments by MRSA or MSSA. The treated

365 and control samples were compared by percent reduction after crystal violet staining and

366 absorbance reading at 595nm. The percent reduction was measured for treatment with

367 vancomycin alone, Ag nanoparticles and vancomycin together and Ag nanoparticles alone. The

368 error bars reflect the standard error and $\mathrm{p}$-values below $0.05(* ; * *$ for $\mathrm{p} \leq 0.01)$ are considered

369 significant. 
371 Table 1: Staphylococcus aureus strains used in this study

\begin{tabular}{|c|c|c|c|c|c|c|c|}
\hline $\begin{array}{l}\text { Strain } \\
\text { name }\end{array}$ & Source & $\begin{array}{l}\text { Susceptib } \\
\text { ility to } \\
\text { methicilli } \\
\text { n }\end{array}$ & $\begin{array}{l}\text { Congo red } \\
\text { colony } \\
\text { morpholog } \\
\text { y }\end{array}$ & $\begin{array}{l}\text { icaD } \\
\text { genotype }\end{array}$ & $\begin{array}{l}\text { Base } \\
\text { biofilm } \\
\text { mass, } \\
\text { OD595 }\end{array}$ & $\begin{array}{l}\% \text { Biofilm } \\
\text { reduction } \\
\text { by } \\
\text { proteinase } \\
\mathrm{K} \\
\text { treatment }\end{array}$ & $\begin{array}{l}\text { \% } \\
\text { Biofilm } \\
\text { reduction } \\
\text { by } \\
\text { DNase } \\
\text { treatment }\end{array}$ \\
\hline M1 & ATF & MRSA & +++ & + & $\begin{array}{l}2.75+/- \\
0.61\end{array}$ & $\begin{array}{l}43.1+/- \\
1.2 \%\end{array}$ & $\begin{array}{l}42.3+/- \\
3.8 \%\end{array}$ \\
\hline M6 & ATF & MRSA & + & - & $\begin{array}{l}3.40+/- \\
0.12\end{array}$ & $\begin{array}{l}43.7+/- \\
0.8 \%\end{array}$ & $\begin{array}{l}51.3+/- \\
2.3 \%\end{array}$ \\
\hline M7 & ATF & MRSA & +++ & - & $\begin{array}{l}2.92+/- \\
0.21\end{array}$ & $\begin{array}{l}44.1+/- \\
0.8 \%\end{array}$ & $\begin{array}{l}58.0+/- \\
2.3 \%\end{array}$ \\
\hline HA1 & $\begin{array}{l}\text { Hospital } \\
\text { isolate }\end{array}$ & MRSA & +++ & + & $\begin{array}{l}2.37+/- \\
0.08\end{array}$ & $\begin{array}{l}\text { 61.2+/- } \\
13.7 \%\end{array}$ & $\begin{array}{l}\text { No } \\
\text { reduction }\end{array}$ \\
\hline $\begin{array}{l}\text { USA300 } \\
\text { GA-92 }\end{array}$ & $\begin{array}{l}\text { BEI } \\
\text { Resources }\end{array}$ & MRSA & ++ & + & $\begin{array}{l}1.28+/- \\
0.10\end{array}$ & $\begin{array}{l}67.8+/- \\
8.8 \%\end{array}$ & $\begin{array}{l}33.2+/- \\
3.7 \%\end{array}$ \\
\hline $\begin{array}{l}\text { SA } \\
29213\end{array}$ & ATCC & MSSA & + & + & $\begin{array}{l}1.24+/- \\
0.11\end{array}$ & $\begin{array}{l}35.1+/- \\
9.2 \%\end{array}$ & $\begin{array}{l}32.9+/- \\
7.3 \%\end{array}$ \\
\hline $\begin{array}{l}\text { SA } \\
12600 \\
\end{array}$ & ATCC & MSSA & +++ & + & $\begin{array}{l}2.26+/- \\
0.10\end{array}$ & $\begin{array}{l}68.3+/- \\
9.3 \%\end{array}$ & $\begin{array}{l}34.4+/- \\
7.3 \%\end{array}$ \\
\hline $\begin{array}{l}\text { SA } \\
4651\end{array}$ & ATCC & MSSA & +++ & + & $\begin{array}{l}0.99+/- \\
0.06\end{array}$ & $\begin{array}{l}59.5+/- \\
5.7 \%\end{array}$ & $\begin{array}{l}48.0+/- \\
7.4 \%\end{array}$ \\
\hline $\begin{array}{l}\text { SA } \\
25923 \\
\end{array}$ & ATCC & MSSA & +++ & + & $\begin{array}{l}1.28+/- \\
0.13\end{array}$ & $\begin{array}{l}\text { No } \\
\text { reduction }\end{array}$ & $\begin{array}{l}54.6+/- \\
6.7 \%\end{array}$ \\
\hline $\begin{array}{l}\text { SA } \\
6538\end{array}$ & ATCC & MSSA & ++ & - & $\begin{array}{l}0.51+/- \\
0.031\end{array}$ & $\begin{array}{l}36.05+/- \\
8.3 \%\end{array}$ & $\begin{array}{l}46.0+/- \\
3.6 \%\end{array}$ \\
\hline
\end{tabular}

373 Strains used in this study included both MRSA and MSSA isolates. ATF=athletic training

374 facility in Utah, BEI Resources (Biodefense and Emerging Infections Research Resources

375 Repository), ATCC (American Type Culture Collection). Standard error is indicated. 


\section{References}

377 1. Gorwitz RJ, Kruszon-Moran D, McAllister SK, McQuillan G, McDougal LK, Fosheim GE, Jensen BJ, Killgore G, Tenover FC, Kuehnert MJ. 2008. Changes in the Prevalence of Nasal Colonization with Staphylococcus aureus in the United States, 2001-2004. Journal of Infectious Diseases 197:1226-1234.

2. Eili K, David LS, Ramanan L. 2007. Hospitalizations and Deaths Caused by Methicillin-Resistant Staphylococcus aureus, United States, 1999-2005. Emerging Infectious Disease journal 13:1840.

3. J W Costerton, Z Lewandowski, D E Caldwell, D R Korber a, Lappin-Scott HM. 1995. Microbial Biofilms. Annual Review of Microbiology 49:711-745.

4. Costerton JW, Geesey GG, Cheng KJ. 1978. How bacteria stick. Sci Am 238:86-95.

5. Hausner M, Wuertz S. 1999. High Rates of Conjugation in Bacterial Biofilms as Determined by Quantitative In Situ Analysis. Applied and Environmental Microbiology 65:3710-3713.

6. Gordon RJ, Lowy FD. 2008. Pathogenesis of methicillin-resistant Staphylococcus aureus infection. Clin Infect Dis 46 Suppl 5:S350-9.

7. Beenken KE, Dunman PM, McAleese F, Macapagal D, Murphy E, Projan SJ, Blevins JS, Smeltzer MS. 2004. Global Gene Expression in Staphylococcus aureus Biofilms. Journal of Bacteriology 186:4665-4684.

8. Joo H-S, Otto M. 2012. Molecular Basis of In Vivo Biofilm Formation by Bacterial Pathogens. Chemistry \& Biology 19:1503-1513.
9. Foulston L, Elsholz AKW, DeFrancesco AS, Losick R. 2014. The Extracellular Matrix of Staphylococcus aureus Biofilms Comprises Cytoplasmic Proteins That Associate with the Cell Surface in Response to Decreasing pH. mBio 5.

10. McCarthy H, Rudkin JK, Black NS, Gallagher L, O'Neill E, O'Gara JP. 2015. Methicillin resistance and the biofilm phenotype in Staphylococcus aureus. Front Cell Infect Microbiol 5:1.

11. Oliveira DC, Tomasz A, de Lencastre H. 2001. The Evolution of Pandemic Clones of MethicillinResistant Staphylococcus aureus: Identification of Two Ancestral Genetic Backgrounds and the Associated mec Elements. Microbial Drug Resistance 7:349-361.

12. Amaral MM, Coelho LR, Flores RP, Souza RR, Silva-Carvalho MC, Teixeira LA, Ferreira-Carvalho BT, Figueiredo AMS. 2005. The Predominant Variant of the Brazilian Epidemic Clonal Complex of Methicillin-Resistant Staphylococcus aureus Has an Enhanced Ability to Produce Biofilm and to Adhere to and Invade Airway Epithelial Cells. Journal of Infectious Diseases 192:801-810.

13. Jevons MP. 1961. "Celbenin" - resistant Staphylococci. British Medical Journal 1:124-125.

14. Voyle-Vavra S, Oliveira DC, Zhang K, Coombs G, O'Brien F, Giffard PM, Westh H, Skov RL, Etienne J, Coleman D, Shore A, Song JH, Soderquist B, Berglund C, Berger-Bachi B, Lauderdale T-L, John JF, Kreiswirth BN, Tenover FC. SCCmec, on The Department of Bacteriology, School of Medicine, Juntendo University. http://www.staphylococcus.net.

15. Hiramatsu K, Cui L, Kuroda M, Ito T. 2001. The emergence and evolution of methicillin-resistant Staphylococcus aureus. Trends in Microbiology 9:486-493.

16. Klevens RM, Edwards JR, Tenover FC, McDonald LC, Horan T, Gaynes R, System. NNIS. 2006. Changes in the epidemiology of methicillin-resistant Staphylococcus aureus in intensive care units in US hospitals, 1992-2003. Clin Infect Dis 42(3):389-91.

17. Hiramatsu K, Hanaki H, Ino T, Yabuta K, Oguri T, Tenover FC. 1997. Methicillin-resistant Staphylococcus aureus clinical strain with reduced vancomycin susceptibility. Journal of Antimicrobial Chemotherapy 40:135-136.

18. Howden BP, Davies JK, Johnson PDR, Stinear TP, Grayson ML. 2010. Reduced Vancomycin Susceptibility in Staphylococcus aureus, Including Vancomycin-Intermediate and Heterogeneous 
461

462

463

464

465

466

467

Vancomycin-Intermediate Strains: Resistance Mechanisms, Laboratory Detection, and Clinical Implications. Clinical Microbiology Reviews 23:99-139.

19. Souli M, Giamarellou H. 1998. Effects of Slime Produced by Clinical Isolates of CoagulaseNegative Staphylococci on Activities of Various Antimicrobial Agents. Antimicrobial Agents and Chemotherapy 42:939-941.

20. Singh R, Ray P, Das A, Sharma M. 2010. Penetration of antibiotics through Staphylococcus aureus and Staphylococcus epidermidis biofilms. Journal of Antimicrobial Chemotherapy 65:1955-1958.

21. Donlan RM, Costerton JW. 2002. Biofilms: survival mechanisms of clinically relevant microorganisms. Clin Microbiol Rev 15(2):167-93.

22. Kollef MH. 2007. Limitations of Vancomycin in the Management of Resistant Staphylococcal Infections. Clinical Infectious Diseases 45:S191-S195.

23. Boucher HW, Corey GR. 2008. Epidemiology of Methicillin-Resistant Staphylococcus aureus. Clinical Infectious Diseases 46:S344-S349.

24. Ansari MA1 KH, Khan AA, Cameotra SS, Alzohairy MA. 2015. Anti-biofilm efficacy of silver nanoparticles against MRSA and MRSE isolated from wounds in a tertiary care hospital. Indian J Med Microbiol 33:101.

25. Chudobova D, Maskova D, Nejdl L, Kopel P, Rodrigo MM, Adam V, Kizek R. 2013. The effect of silver ions and silver nanoparticles on Staphylococcus aureus, vol 1. Formatex Research Center.

26. Ayala-Núñez NV, Lara Villegas HH, del Carmen Ixtepan Turrent L, Rodríguez Padilla C. 2009. Silver Nanoparticles Toxicity and Bactericidal Effect Against Methicillin-Resistant Staphylococcus aureus: Nanoscale Does Matter. NanoBiotechnology 5:2-9.

27. Xu H, Qu F, Xu H, Lai W, Andrew Wang Y, Aguilar ZP, Wei H. 2012. Role of reactive oxygen species in the antibacterial mechanism of silver nanoparticles on Escherichia coli 0157:H7. BioMetals 25:45-53.

28. Wady AF, Machado AL, Foggi CC, Zamperini CA, Zucolotto V, Moffa EB, Vergani CE. 2014. Effect of a Silver Nanoparticles Solution on Staphylococcus aureus and Candida spp. Journal of Nanomaterials 2014:7.

29. Jensen KC, Hair BB, Wienclaw TM, Murdock MH, Hatch JB, Trent AT, White TD, Haskell KJ, Berges BK. 2015. Isolation and Host Range of Bacteriophage with Lytic Activity against MethicillinResistant Staphylococcus aureus and Potential Use as a Fomite Decontaminant. PLoS One 10:e0131714.

30. Morones-Ramirez JR, Winkler JA, Spina CS, Collins JJ. 2013. Silver Enhances Antibiotic Activity Against Gram-Negative Bacteria. Science Translational Medicine 5:190ra81-190ra81.

31. Hwang I-s, Hwang JH, Choi H, Kim K-J, Lee DG. 2012. Synergistic effects between silver nanoparticles and antibiotics and the mechanisms involved. Journal of Medical Microbiology 61:1719-1726.

32. Habash MB, Park AJ, Vis EC, Harris RJ, Khursigara CM. 2014. Synergy of Silver Nanoparticles and Aztreonam against Pseudomonas aeruginosa PAO1 Biofilms. Antimicrobial Agents and Chemotherapy 58:5818-5830.

33. Fu PP, Xia Q, Hwang HM, Ray PC, Yu H. 2014. Mechanisms of nanotoxicity: generation of reactive oxygen species. J Food Drug Anal 22:64-75.

34. Li WR, Xie XB, Shi QS, Duan SS, Ouyang YS, Chen YB. 2011. Antibacterial effect of silver nanoparticles on Staphylococcus aureus. Biometals 24:135-41.

35. Mirzajani F, Ghassempour A, Aliahmadi A, Esmaeili MA. 2011. Antibacterial effect of silver nanoparticles on Staphylococcus aureus. Res Microbiol 162:542-9. 
36. Masurkar SA, Chaudhari PR, Shidore VB, Kamble SP. 2012. Effect of biologically synthesised silver nanoparticles on Staphylococcus aureus biofilm quenching and prevention of biofilm formation. IET Nanobiotechnol 6:110-4.

37. Gomez-Carretero S, Nybom R, Richter-Dahlfors A. 2017. Electroenhanced Antimicrobial Coating Based on Conjugated Polymers with Covalently Coupled Silver Nanoparticles Prevents Staphylococcus aureus Biofilm Formation. Adv Healthc Mater 6:e1700435.

38. Habash MB, Park AJ, Vis EC, Harris RJ, Khursigara CM. 2014. Synergy of silver nanoparticles and aztreonam against Pseudomonas aeruginosa PAO1 biofilms. Antimicrob Agents Chemother 58:5818-30.

39. Freeman DJ, Falkiner FR, Keane CT. 1989. New method for detecting slime production by coagulase negative staphylococci. J Clin Pathol 42:872-874.

40. Gowrishankar S, Kamaladevi A, Balamurugan K, Pandian SK. 2016. In Vitro and In Vivo Biofilm Characterization of Methicillin-Resistant Staphylococcus aureus from Patients Associated with Pharyngitis Infection. Biomed Res Int 2016:1289157.

41. Adwan K. 2014. Fast DNA isolation and PCR protocols for detection of methicillin-resistant staphylococci. Folia Microbiol (Praha) 59:5-8.

42. Namvar AE, Asghari B, Ezzatifar F, Azizi G, Lari AR. 2013. Detection of the intercellular adhesion gene cluster (ica) in clinical Staphylococcus aureus isolates. GMS Hyg Infect Control 8:Doc03.

43. Cassat JE, Lee CY, Smeltzer MS. 2007. Investigation of Biofilm Formation in Clinical Isolates of Staphylococcus aureus. Meth Mol Biol 391:127-44.

44. Christensen DG, Simpson WA, Younger JJ, Larry M, Barrett FF, Melton DM, Beachy E. 1985. Adherence of coagulase-negative staphylococci to plastic tissue culture plates: a quantitative model for the adherence of staphylococci to medical devices. J Clin Microbiol 22:996-1006. 
bioRxiv preprint doi: https://doi.org/10.1101/337436; this version posted June 2, 2018. The copyright holder for this preprint (which was not certified by peer review) is the author/funder, who has granted bioRxiv a license to display the preprint in perpetuity. It is made available under aCC-BY-ND 4.0 International license.

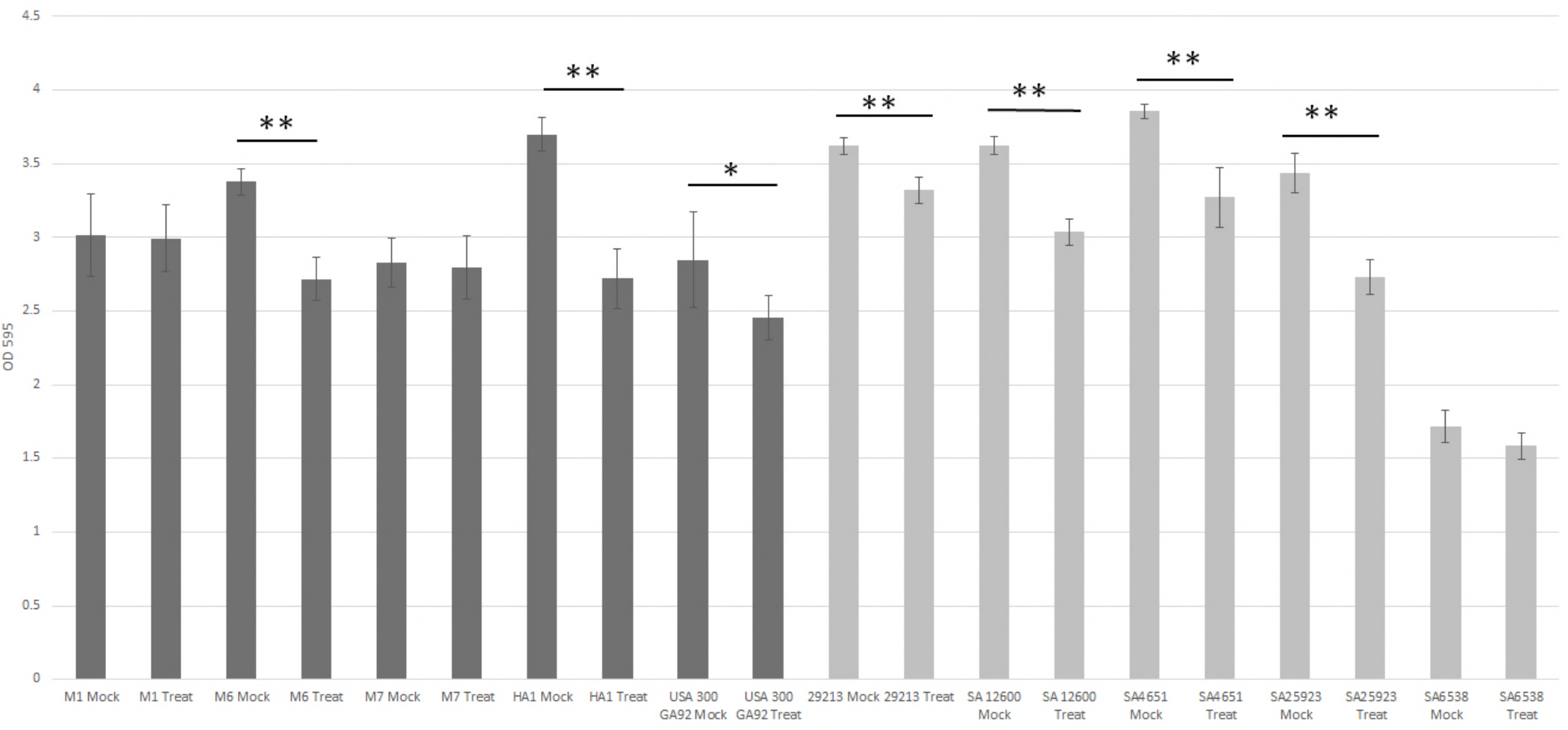


bioRxiv preprint doi: https://doi.org/10.1101/337436; this version posted June 2, 2018. The copyright holder for this preprint (which was not certified by peer review) is the author/funder, who has granted bioRxiv a license to display the preprint in perpetuity. It is made available under aCC-BY-ND 4.0 International license.

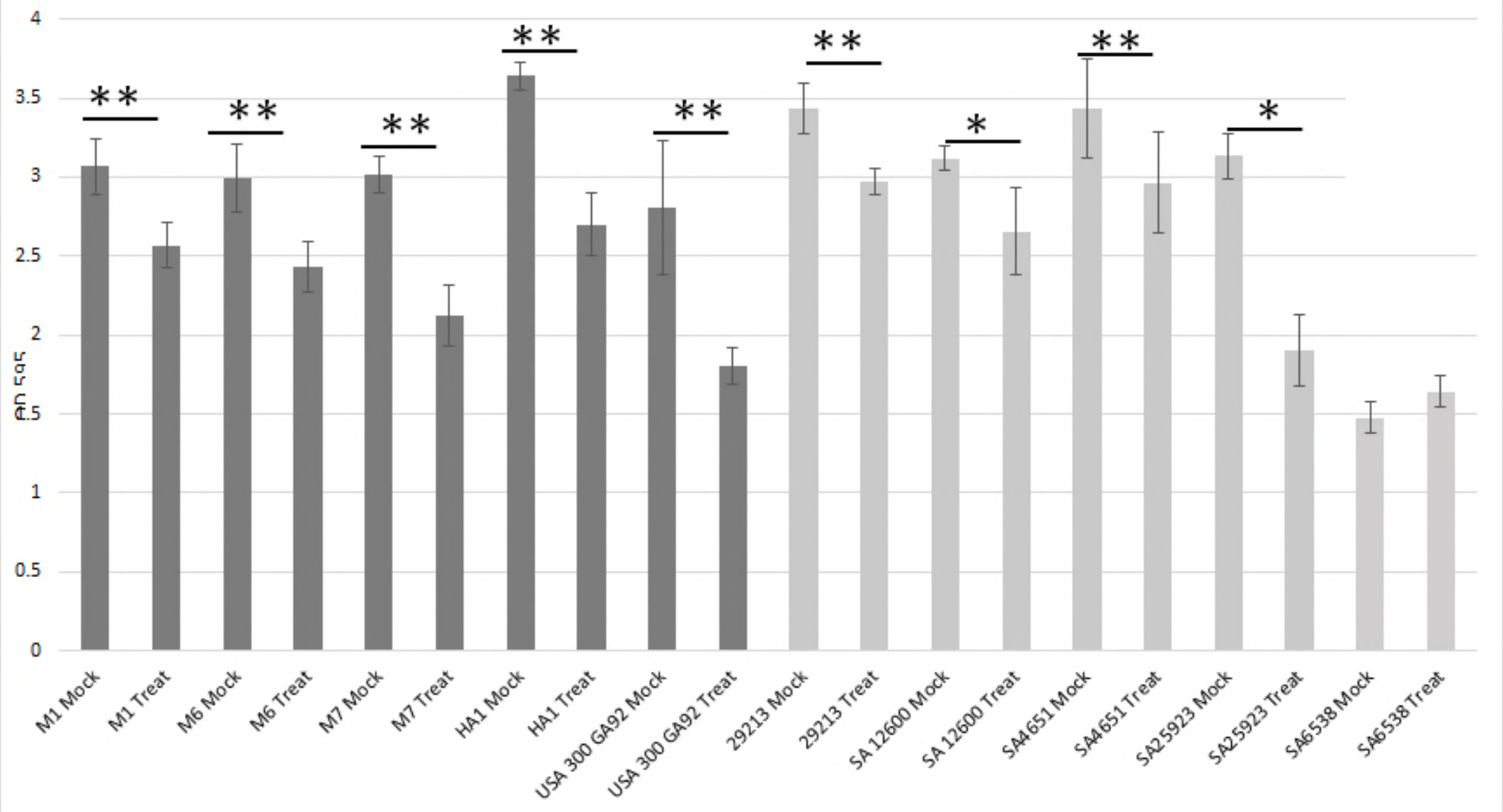


bioRxiv preprint doi: https://doi.org/10.1101/337436; this version posted June 2, 2018. The copyright holder for this preprint (which was not certified by peer review) is the author/funder, who has granted bioRxiv a license to display the preprint in perpetuity. It is made available under aCC-BY-ND 4.0 International license.

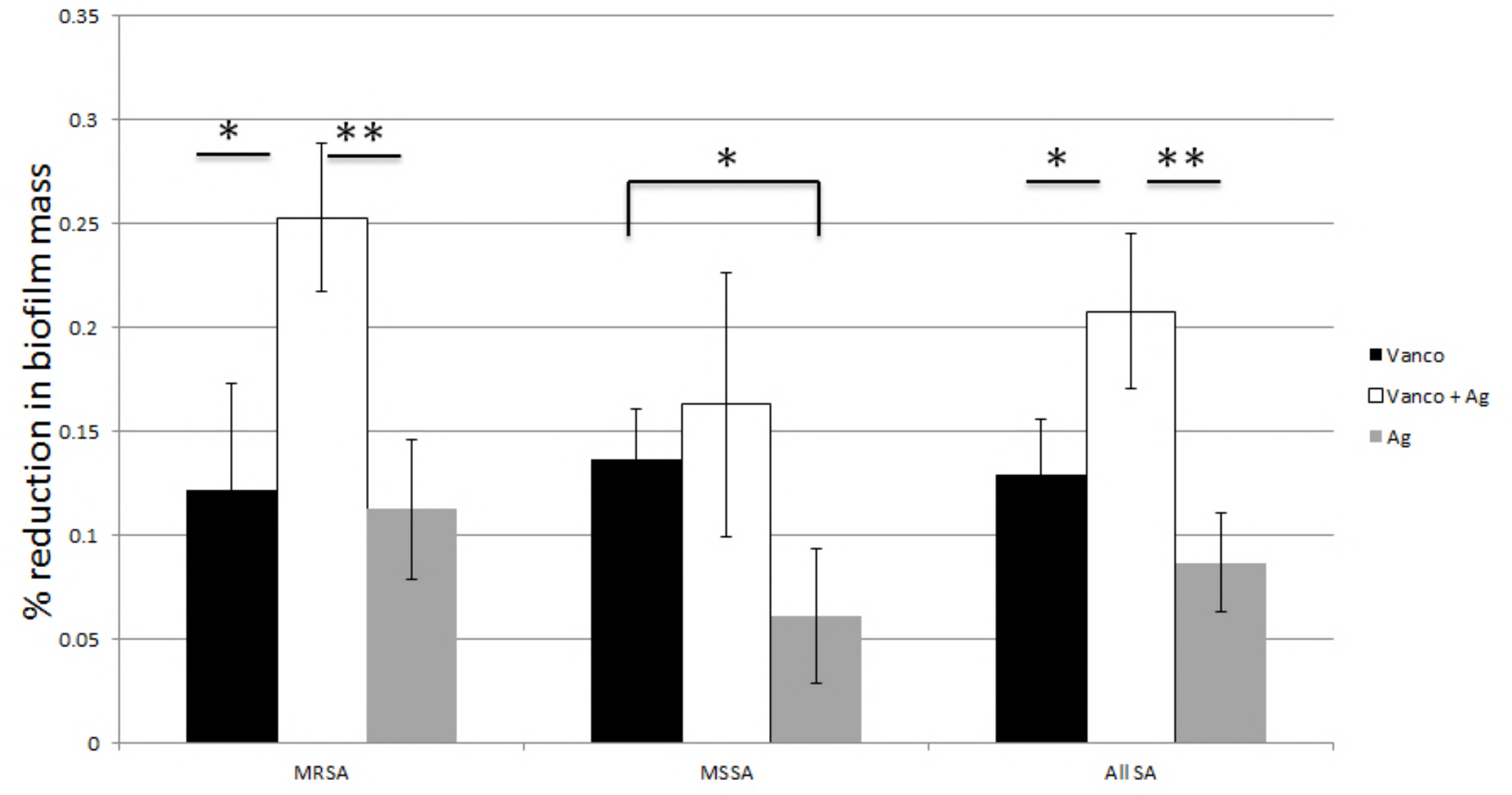

